\title{
Relationship between Employee Quality Development and Work Productivity of the Forestry and Plantation Service Office of Purwakarta Regency
}

\author{
Budi Rismayadi \\ Faculty of Economic and Business, University of Buana Perjuangan Karawang, Indonesia \\ Email: budi.rismayadi@ubpkarawang.ac.id
}

\begin{abstract}
The purpose of this research is to determine the relationship between employee quality development and work productivity of employees at the Forestry and Plantation Service of Purwakarta Regency. The research method used is a verification research method with multiple linear regression models, the data processing uses multiple correlation analysis and uses the $\mathrm{F}$ test and $\mathrm{T}$ test. The population is all employees of the Purwakarta district health and plantation office, with a sample of 50 people. The variable used is the Quality Development variable as the $X$ variable, which consists of two variables, namely: the $X_{1}$ training variable and the $X_{2}$ course variable, while the work productivity is the $Y$ variable. The results of the study show that training and courses on work productivity are obtained $F$ count $>F$ table namely 4,375>3,767 indicates that there is a significant relationship between development variables on work productivity, development variables on work productivity. The results of correlation analysis between variables have a correlation coefficient between training and work productivity 0.491 ; between courses with work productivity 0.473 . Of the two independent variables, the training variable has a correlation coefficient value greater than the course variable. The coefficient value of 0.491 indicates a moderate interpretation for the training and work productivity variables. The coefficient of determination (R2) between the training and course variables is $\mathbf{2 8} \%$, the remaining $72 \%$ is influenced by other factors. In other words, the variable of employee quality development in the Forestry and Plantation Service of Purwakarta Regency is not the superior variable in increasing work productivity. From the results of the regression analysis, the percentage increase in variable $X$ to $Y$ is obtained as follows: to achieve maximum productivity, amounting to $27.129 \%$; training $27.050 \%$, and courses $27.061 \%$. Of the existing variables, training only required an increase of $27.050 \%$.
\end{abstract}

Keywords: Employee Quality Development, Employee Work Productivity.

\section{A. INTRODUCTION}

Increasing the ability of resources cannot be separated from efforts to increase human resources, therefore development which is the second operational function of personnel management needs to be carried out in a planned and sustainable manner (Bowen \& Lawler, 1992). In order for development to be carried out properly, a program for developing the quality of employees must first be established. It is felt that the development of the quality of employees is of increasing importance due to the demands of work or position, as a result of technological advances and increasingly intense competition among similar companies. Every company personnel is required to 
work effectively, efficiently, with good quality and quantity of work so that the company's competitiveness is getting bigger (Youndt et al., 1996).

Employee quality development is carried out for non-career and career purposes for employees (new or old) through formal development and informal development (Zeitz et al., 1997). Therefore, with the development of the quality of employees it is expected to have high work productivity. Human resource development is a planned and sustainable effort made by management to improve employee competence and organizational performance (Djuwita, 2011). In other words, employee development is any activity intended to change people's behavior consisting of knowledge, skills and attitudes (Husein, 2014).

Work productivity is the ability to produce goods and services from various resources or production factors that are used to improve the quality and quantity of work produced in a company, while work productivity is influenced by the level of education, training, work motivation, work ethic, mental and physical abilities of workers concerned (Simanjuntak, 2011). In order to be able to produce or produce maximum and optimal goods, the company must achieve high company productivity through reliable labor selection in addition to increasing the ability of the workforce with various trainings, it is hoped that they will be able to have experience (Rismayadi, 2016).

So with the development of employee quality it is hoped that there will be work motivation so that it will increase employee work productivity. Hasibuan (2011) said that there are 4 types of employee development, namely: 1. employee promotion 2. education and training 3. job performance appraisal 4. employee transfer. "Even though human resources have been given quality development, if management factors others are not supportive, so motivation cannot be expected as it should be (Chen et al., 2006). If the employee's motivation is low, the employee will work as needed or work below their actual ability. On the other hand, high employee motivation will benefit the company (Widyalova et al., 2019).

The quality of employee development can provide benefits for long-term human resource development and reduce the recruitment of new employees, provide opportunities for old employees to have careers, anticipate employee obsolescence and workforce turnover (Rismayadi \& Maemunah, 2016).

\section{B. METHOD}

The research method used in this research is associative research, which is a study that aims to determine the relationship between two or more variables. The pattern used in this method is correlational, which is used to find the relationship between one variable and another (Sugiyono, 2018). The research method is a scientific method used to obtain objective, valid and reliable data with the aim of being able to find, prove and develop knowledge, so that it can be used to understand, solve, and 
anticipate problems (Arikunto, 1998). Correlational studies is a study that is intended to determine whether there is a relationship between two or more variables. Instrumentation used to obtain research data is the Likert scale technique. The author uses the Likert scale because the Likert scale is a tool for measuring attitudes, opinions and perceptions of a person or group of people about social phenomena. This scale is designed in such a way, where every one question that becomes a question in the questionnaire has two characteristics, namely a pleasant (positive) and an unpleasant (negative) attitude.

The population is all employees of the Purwakarta District Forestry and Plantation Service. Arikunto (1998) said that the population is the entire research subject. In this study the dependent variable is the work productivity of employees who are given the symbol $Y$, then the independent variable is employee development given the symbol $X$, then this development is divided into two namely through training variable $X_{1}$, and through a course of variable $X_{2}$.

Samples were taken 50 employees of the Forestry and Plantation Service. The sampling technique that represents the study population (Umar, 2012) is as follows:

$$
\mathrm{n}=\frac{N}{1+N e^{2}}
$$

Where:

$\mathrm{n}$ = sample size

$\mathrm{N}=$ population size

$\mathrm{e}=$ critical value $(5 \%)$

This sampling technique is done by using a simple random sampling probability technique, because the sampling of population members is done randomly without regard to strata that exist in the population. The collection techniques used to obtain research data include: documentation, interviews and questionnaires.

\section{RESULT AND DISCUSSION}

The results of the correlation testing research to observe and analyze the extent to which the observed variables are relevant to the increased level of work productivity using statistical analysis, are as follows:

\section{Correlation Analysis between Variables}

1) Correlation Analysis Between Training Variables Against Work Productivity The results obtained a correlation coefficient value of:

$$
\begin{aligned}
r_{x y} & =\frac{77,360}{(133,120)(186,580)} \\
& =0.491
\end{aligned}
$$


2) Correlation Analysis Between Course Variables Against Work Productivity The results obtained a correlation coefficient value of,

$$
\begin{aligned}
r_{x y} & =\frac{84,000}{(212,000)(148,500)} \\
& =0.473
\end{aligned}
$$

\section{Regression Analysis between Variables}

\section{a. Simple Regression}

We use regression analysis if we want to find out how the dependent variable can be predicted through independent variables or predictors, individually. The impact of using regression analysis can be used to decide whether an increase or decrease in the dependent variable can be done through increasing or decreasing the state of the independent variable or to increasing the state of the independent variable can be done by increasing the independent variable and vice versa (Saidah et al., 2016). Regression can be found using the following formula: $\mathrm{Y}=\mathrm{a}+\mathrm{b} \mathrm{X}$

Where:

$\mathrm{Y}=$ subjects in the predicted dependent variable

$\mathrm{a}=$ price $\mathrm{Y}$ if $=0$ (constant price)

$b=$ the direction number or regression coefficient, which shows the rate of increase or decrease in the dependent variable, if $b(+)$ increases and if b (-) then decreases.

$X=$ subject to the independent variable that has a certain value.

Where the values of $b$ and a are found using the equation:

$$
\begin{aligned}
\mathrm{b} & =\frac{n \Sigma X Y-\Sigma X(\Sigma Y)}{n \Sigma X^{2}-(\Sigma X)^{2}} \\
\mathrm{a} & =\mathrm{y}-\mathrm{bX} \\
\bar{Y} & =\frac{\Sigma Y}{n} \\
\bar{X} & =\frac{\Sigma X}{n}
\end{aligned}
$$

1) Regression Analysis Between Training Variables on Work Productivity The result is a regression equation as follows:

$$
\begin{aligned}
& \mathrm{b}=\frac{50(8066)-712(561)}{50(10722)-(712)^{2}} \\
&=0.581 \\
& \mathrm{a}=11.22-0.581(14.24) \\
&=2.945 \\
& \text { So, } \mathrm{Y}=2.945+0.581 \mathrm{X}
\end{aligned}
$$


- Total score of 50 respondents for work productivity variable

Actual $=1168$ (see appendix 7)

Expected $=4 \times 8 \times 50=1600$

From the multiple regression equation between training and work

productivity, the following equation is obtained: $\mathrm{Y}=2.945+0.581 \mathrm{X}$

- Expected productivity:

$$
\begin{aligned}
& 1600-2.945+0.581 X \\
& X=2748.804
\end{aligned}
$$

- Existing productivity reality:

$1168-2.945+0.581 X$

$X=2005.258$

So\% increase in training for work productivity

$$
=\frac{2748.804-2005.258}{2748.804} \times 100 \%=27.050 \%
$$

This means that if employee work productivity is to be increased through training programs, company management needs to increase by $27.050 \%$.

2) Regression Analysis Between Course Variables Against Work Productivity The result is a regression equation as follows:

$$
\begin{aligned}
\mathrm{b} & =\frac{50(5354)-620(452)}{50(7900)-(620)^{2}} \\
& =0.396 \\
\mathrm{a} & =8.5-0.396(12.4) \\
& =3.5887
\end{aligned}
$$

So, $\mathrm{Y}=3.587+0.396 \mathrm{X}$

- Total score of 50 respondents for work productivity variable

$$
\begin{array}{ll}
\text { Actual } & =1168 \\
\text { Expected } & =4 \times 8 \times 50=1600
\end{array}
$$

From the multiple regression equation between courses on work productivity the following equation is obtained:

$$
\mathrm{Y}=3.587+0.396 \mathrm{X}
$$

- Expected productivity:

$$
\begin{aligned}
& 1600-3.587+0.396 X \\
& X=4031.346
\end{aligned}
$$

- Existing productivity reality:

$$
\begin{aligned}
& 1168-3.587+0.396 X \\
& X=2940.437
\end{aligned}
$$

So\% increase in training for work productivity

$$
=\frac{4031.346-2940.437}{4031.346} \times 100 \%=27.061 \%
$$


This means that if employee work productivity is to be increased through course courses, then company management needs to increase by $27.061 \%$.

\section{b. Multiple Regression}

This study consists of two independent variables which are considered to have an effect on work productivity at the Forestry and Plantation Service of Purwakarta Regency. The independent variables studied include the training variable $\left(X_{1}\right)$ and the course variable $\left(X_{2}\right)$. Based on the calculation results of the SPSS for Window 10.0 program, the independent variables have an influence on the dependent variable. This can be seen from the results of the calculation of multiple regression analysis in table 1.1 below:

Table 1.1 Results of the calculation of Multiple Regression Analysis

\begin{tabular}{|c|c|c|c|c|}
\hline \multirow[t]{2}{*}{ Mode } & \multirow{2}{*}{$\begin{array}{c}\text { Unstandardized } \\
\text { Coefficients }\end{array}$} & \multicolumn{3}{|c|}{ ANOVA } \\
\hline & & $\mathrm{R}$ & R square & $\mathrm{F}$ \\
\hline (Constant) & 0.685 & 0.529 & 0.280 & 4.375 \\
\hline Training & 0.485 & & & \\
\hline Courses & 0.183 & & & \\
\hline
\end{tabular}

Based on table 1.1 above can be included in the multiple regression analysis model as follows:

$$
\begin{aligned}
& \mathrm{Y}=0.685+0.485 \mathrm{X} 1+0.183 \mathrm{X} 2 \\
& \mathrm{R}_{2}=0.280
\end{aligned}
$$

The results of the calculation of the regression equation mean; a constant of 0.685 states that if there is no improvement in the quality of employees, work productivity will remain at 0.685 .

The regression equation coefficient shows that the variable $X_{1}$ provides a regression coefficient of $0.485 \%$. This shows that if there is an increase (cost) of training $1 \%$ will affect the increase in work productivity by $0.485 \%$.

The result of linear regression calculation for the course variable $\left(\mathrm{X}_{2}\right)$ produces a regression coefficient of 0.183 . This means that if the course variable is fixed by $1 \%$ it will have a positive effect on work productivity.

\section{Research Hypothesis Testing}

1) Testing the Associative Hypothesis between Training and Work Productivity Research hypothesis:

a. $\mathrm{H}_{0}, \mathrm{H}_{0}$ is accepted if $\mathrm{t}$ count $<\mathrm{t}$ table; it means "there is no significant relationship between training and work productivity".

b. $\mathrm{H}_{\mathrm{a}}, \mathrm{H}_{0}$ is rejected if $\mathrm{t}$ count $<\mathrm{t}$ table; it means "there is a significant relationship between training and work productivity". 


$$
t=\frac{0,491 \sqrt{50-2}}{1-\left(0,491^{2}\right.}=3,906
$$

Therefore $t$ count (3.906) $>t$ table (2.682) then the null hypothesis $\left(\mathrm{H}_{0}\right)$ is rejected, meaning that there is a significant relationship between training and work productivity.

2) Testing the Associative Hypothesis Between Courses and Work Productivity Research hypothesis:

$\mathrm{H}_{0}, \mathrm{H}_{0}$ is accepted if $\mathrm{t}_{\text {count }}<\mathrm{t}$ table; it means "there is no significant relationship between courses and work productivity".

$\mathrm{H}_{\mathrm{a}}, \mathrm{H}_{0}$ is rejected if $\mathrm{t}$ count $<\mathrm{t}$ table; it means "there is a significant relationship between courses and work productivity".

$$
\mathrm{t}=\frac{0,473 \sqrt{50-2}}{1-(0,473)^{2}}=3,720
$$

Therefore $t$ arithmetic $(3,720)>t$ table $(2,682)$ then the null hypothesis $\left(\mathrm{H}_{0}\right)$ is rejected meaning that there is a significant relationship between the Course with work productivity.

The research results can be concluded that the provisional hypothesis in this study has been proven theoretically and empirically. The answer to the hypothesis which says that there is a significant relationship between the variables of employee quality development and work productivity. Employee quality development through formal and informal development can generate employee work motivation which in turn can increase work productivity.

The correlation coefficient values obtained from the analysis of the variables mentioned above mostly have moderate interpretations and have been tested for validity and reliability. This shows that with the development of the quality of employees, technical, theoretical, conceptual and employee moral capabilities can be improved. Of the existing variables, training has a correlation coefficient value that is much greater than that of courses in increasing work productivity. This is related that according to training theory is a teaching and learning process that requires the ability of concepts, attitudes or knowledge from people to help achieve goals.

The Forestry and Plantation Office of Purwakarta Regency, in this case, is trying to improve training - training that is in the nature of quality management, in which employees doing work that affect product quality must be competent based on the training that is followed.

1. Variable training on work productivity

The results obtained between $t$ count (3.906) $<t$ table (2.682) means that there is a significant relationship between training and work productivity. The correlation coefficient value of 0.491 indicates a moderate interpretation, from the development of the quality of employees, training is a variable that has a correlation coefficient value 
greater than other variables. The result of regression analysis $\mathrm{Y}=2.945+0.581 \mathrm{X}$, expected productivity of 2 748.804, existing productivity in 2005.258. To achieve maximum productivity, the head of the agency strives to increase it by $27.050 \%$ from the previous cost allocation, so that the expected productivity is achieved.

2. Course variables on work productivity

Based on the results obtained between $t$ count (3.720) $<t$ table (2.682) there is a significant relationship between the course with work productivity. The correlation coefficient of 0.473 indicates a moderate interpretation.

3. Variable training, courses on work productivity

The results of the calculation between the two independent variables and the dependent variable obtained the multiple regression line equation $\mathrm{Y}=0.685+0.485 \mathrm{X} 1+$ $0.183 \times 2$. Taken together, training and course variables can affect work productivity. From the two independent variables, both of them have positive regression coefficient. The development of the quality of employees at the Purwakarta Regency Forestry and Plantation Service through training is one of the variables for developing the quality of employees that must be of concern to the leadership of the Purwakarta Regency Forestry and Plantation Service in managing its human resources. The attention of the leadership to the fulfillment of the development of employee quality which ultimately can increase work productivity, so the most important is how to determine the competencies needed for employees who do the work.

In the end, it must be understood that to improve work productivity through developing employee quality, it is necessary to further study the agency because the effect is only $28 \%$, which means that $72 \%$ is influenced by other variables.

\section{CONCLUSION}

The results of research between variables with a significant level of $1 \%$ show a significant relationship between employee quality development through training and courses, on work productivity. Hypothesis testing jointly, namely training and course variables on work productivity obtained $\mathrm{F}$ count $>\mathrm{F}$ table, namely $4.375>3.767$ shows that there is a significant relationship between development variables on work productivity.

The results of the correlation analysis between variables have a correlation coefficient between training and work productivity of 0.491 ; between courses with work productivity 0.473 . Of the two independent variables, the training variable has a correlation coefficient value greater than the course variable. The coefficient value of 0.491 indicates a moderate interpretation for the training and work productivity variables. The coefficient of determination $\left(\mathrm{R}^{2}\right)$ between the training and course variables is $28 \%$, the remaining $72 \%$ is influenced by other factors. In other words, the variable of employee quality development in the Forestry and Plantation Service of Purwakarta Regency is not the superior variable in increasing work productivity. 
From the results of the regression analysis, the percentage increase in variable $X$ to $\mathrm{Y}$ is obtained as follows: to achieve maximum productivity, amounting to $27.129 \%$; training $27.050 \%$, and courses $27.061 \%$. Of the existing variables, training only required an increase of $27.050 \%$. The level of representation of the number of samples entered according to the Husain Umar formula, the critical value of the incoming sample is $11 \%$, meaning that the confidence level of the incoming sample is $89 \%$ meaning that with a $89 \%$ confidence level the incoming sample can be accepted as a research sample.

Carrying out employee quality development in stages, namely by holding training or taking other actions to meet the needs achieved. Employee who has participated in quality development is expected to gain additional knowledge and maintain proper records of developments that are followed and the agency conducts evaluations to employees who have follow development and can follow up on what kinds of development employees need to achieve goals. To improve work productivity, the agency not only focuses on developing employee quality (only $28 \%$ of its participation), but on other variables, which is $72 \%$, such as compensation and motivation.

\section{REFERENCES}

1. Arikunto, S. (1998). Metodologi Penelitian Suatu Pendekatan Praktek. Jakarta: Rineka Cipta.

2. Bowen, D. E., \& Lawler III, E. E. (1992). Total quality-oriented human resources management. Organizational dynamics, 20(4), 29-41.

3. Chen, S. H., Yang, C. C., Shiau, J. Y., \& Wang, H. H. (2006). The development of an employee satisfaction model for higher education. The TQM Magazine.

4. Hasibuan, M. S. P. (2011). Manajemen Sumber Daya Manusia. Jakarta: Bumi Aksara.

5. Husein, U. (2014). Riset Sumber Daya Manusia Dalam Organisasi. Jurnal Riset Akuntansi dan Bisnis, 14.

6. Rismayadi, B. (2016). Faktor-Faktor yang Mempengaruhi Produktivitas Karyawan (Studi Kasus pada CV Mitra Bersama Lestari Tahun 2014). Jurnal Manajemen E Bisnis Kreatif, 1(1). https://doi.org/10.36805/manajemen.v1i1.53

7. Rismayadi, B., \& Maemunah, M. (2016). Pengaruh Motivasi Kerja, Kepemimpinan dan Budaya Organisasi Terhadap Kepuasan Kerja Karyawan serta Dampaknya pada Kinerja Perusahaan (Studi kasus pada PT. Concord Indonesia). Jurnal Manajemen $\mathcal{E}$ Bisnis Kreatif, 2(1). https://doi.org/10.36805/manajemen.v2i1.181

8. Saidah, Yanuar, F., \& Devianto, D. (2016). Analisis Regresi Analisis Regresi. Jurnal Matematika UNAND, 5(1).

9. Simanjuntak, P. (2011). Manajemen dan Evaluasi kinerja. In Lembaga Penerbit Fakultas Ekonomi Universitas Indonesia: Jakarta.

10. Sugiyono. (2018). Metode Penelitian Kuantitatif,Kualitatif dan RED. Bandung: Alfabeta. 
11. Djuwita, T. M. (2011). Pengembangan Sumber Daya Manusia dan Produktivitas Kerja Pegawai. Manajerial: Jurnal Manajemen dan Sistem Informasi, 10(2), 15-21.

12. Umar, H. (2012). Penelitian Kuantitatif langkah demi langkah. Pelatihan Metodologi Penelitian Kopertis III, Mei.

13. Widyalova, W., Rismayadi, B., \& Anggela, F. P. (2019). Pengaruh Motivasi dan Disiplin Kerja Terhadap Kinerja Karyawan Di Management Office Resinda Park Mall Karawang. BUANA ILMU, 4(1), 169-173.

14. Youndt, M. A., Snell, S. A., Dean Jr, J. W., \& Lepak, D. P. (1996). Human Resource Management, Manufacturing Strategy, and Firm Performance. Academy of Management Journal, 39(4), 836-866.

15. Zeitz, G., Johannesson, R., \& Ritchie Jr, J. E. (1997). An Employee Survey Measuring Total Quality Management Practices and Culture: Development and Validation. Group \& Organization Management, 22(4), 414-444. 